分析：物犋: $0.045 \check{5} \mathrm{~g}$

$\mathrm{C}_{13} \mathrm{H}_{11} \mathrm{O}_{2} \mathrm{Br}$ としての理論數 物筫: $0.0317 \mathrm{~g}$

$\mathrm{C}_{12} \mathrm{H}_{8} \mathrm{OPr}\left(\mathrm{OCH}_{3}\right)$ としての理論數
$\mathrm{AgBr}: 0.0309 \mathrm{~g}$

$\mathrm{Br}: \quad 28.90 \%$

$\mathrm{Br}: 28.65 \%$

$\mathrm{OCH}_{3}: 10.95 \%$

$\mathrm{OCH}_{3}: 11.12 \%$

12) 2-Oxy-2'-brom-diphenylaether (XII)

上記 8）に於けると全く同樣に 2-Methoxy-2'-brom-diphenylaether よりブロム水素酸水醋 で脫メチルした。無色油狀物質 $\mathrm{Kp}_{4} 140^{\circ}$. 過クロル鐵で極めて微に㣴綠色(アルコール溶液).

佔, この㧤メチル反應に於て, 目的物以外に, Fp 96-101の白色結晶が少量得られた. 本物 質は，苛性アルカリに可溶で，ブロムの反應を付する．得量は目的物のそれの約 1-4\%で, 微 量の䉆, 精柾しなかつた。

分析：物質: $0.0449 \mathrm{~g}$

$\mathrm{AgBr}^{2}: 0.0316 \mathrm{~g}$

$\mathrm{Pr}: 29.95 \%$

$\mathrm{C}_{12} \mathrm{H}_{9} \mathrm{O}_{2} \mathrm{Br}$ としての理論数

$\operatorname{Br}: 20.2 \%$

13) 2-Oxy-2'-brom-diphenylaeather $\oslash$ 閉環.

物質 $1 \mathrm{~g}$ をメタノールに溶かし, 金屬カリ $0.15 \mathrm{~g}$ を㞦へてカリ監となし, 減俩でメタノール を除き，殘渣に Naturkupfer C 及び Kupferacetat 各飞 $0.04 \mathrm{~g}$ 宛を加へ，190-200 の油浴中 3 時間加熱する. 冷後, 器壁に Diphenylendioxyd の結晶が昇華して居るのが認められる. 反 應物をェーテルで骎出し, エーテル溶液は苛性ソーダ液で振蕰してフェノール性物質を除き, 声 硝で乾燥後, 溶媒を蒸溜し, 殘渣を真空昇華に附すると, 白色針狀結晶が得られる. 得量 $0.15 \mathrm{~g}$, てのものは Fp $116^{\circ}$ であるが, Ullmann の方法で製した Diphenylendioxyd (第 4 項参照)と の混融は $119^{\circ}$ を示す. 硫硝酸による所謂 Diphenylendioxyd の反應顯著.

\title{
市販グルコン酸石灰 (粉末及び注射液)の比較
}

\author{
慶 松一郎 \\ 西原陽子 \\ （三藥病院薬局） \\ (炤和 11 年 9 月 7 日受理)
}

表題の䒚品は, 外國品一種に對し, 國產品が數種も輩出して居る。本試驗が行はれた主な動 機は，之等の選擇に對して一の標準を得るにあつた。

試驗には，購入术販品を供し，それを以て該商品の代表と見做した。佾注射液は，同一種の 
市販品を，月日を異にして 2 回宛購入して比較したが，兩包の標品間に差異は認められなかつ た.

供試標品は，粉末，注射液共 $\mathrm{A}-\mathrm{F}$ なる記號で示す．同一記號の粉末と注射は，同一會社の 製品である. 而して A は外國品， B-F は國產品である.

I）粉末に就て：a）溶解度以外の試驗：一覽表で示す.

\begin{tabular}{|c|c|c|c|c|c|c|c|c|c|c|c|}
\hline \multirow{2}{*}{\multicolumn{2}{|c|}{$\begin{array}{l}\text { 試 } \\
\text { 检 } \\
\text { 末 }\end{array}$}} & \multicolumn{3}{|c|}{ 水分 の 测定 $(\%)$} & \multirow{2}{*}{\multicolumn{3}{|c|}{ 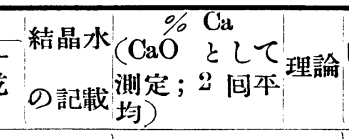 }} & & \multirow{2}{*}{$\begin{array}{l}\mathrm{Ca} \cdot \\
\mathrm{SO}_{4}^{\prime \prime} \\
\mathrm{NO}_{3}^{\prime}\end{array}$} & \multirow[b]{2}{*}{$\begin{array}{l}\text { ハロゲ } \\
\text { イオン }\end{array}$} \\
\hline & & 常溫恒量 & $\begin{array}{l}\text { 更に100- } \\
110^{\circ} に \text { 燥 } \\
\text { 乾 }\end{array}$ & $\begin{array}{l}\text { 更に120- } \\
140^{\circ} \text { に榦 } \\
\text { 燥 }\end{array}$ & & & & $\left\{\begin{array}{l}{[\alpha]_{\mathrm{B}}^{34} \text { (水溶液 }} \\
(2 \text { 问本均) }\end{array}\right.$ & 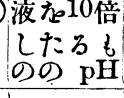 & & \\
\hline & A & 0.4 & 0.3 & - & \multirow{4}{*}{$0 \%$} & 8.5 & \multirow{4}{*}{9.3} & $+8.1^{\circ}$ & 5.6 & - & +- \\
\hline & B & 0.4 & 0 & - & & 9.1 & & $+8.3^{\circ}$ & $5.4-5.6$ & - & - \\
\hline & $\mathbf{C}$ & 0.5 & 0.1 & - & & 10.6 & & $+8.3^{\circ}$ & "I & - & - \\
\hline & $\mathrm{D}$ & 0.4 & 0.7 & - & & 9.4 & & $+8.7^{\circ}$ & " & - & 一 \\
\hline & $E$ & 0.3 & 0 & 岑化 & \multirow{2}{*}{$\begin{array}{l}2 \mathrm{H}_{2} \mathrm{O} \\
(7.7 \%)\end{array}$} & 7.9 & \multirow[b]{2}{*}{$8.6(?)$} & $+7.9^{\circ}$ & $\prime \prime$ & - & + \\
\hline & $\mathbf{F}$ & 0.5 & 0.6 & "I & & & & $+8.8^{\circ}$ & 5.6 & - & - \\
\hline
\end{tabular}

對 稱

Ca-gluconat

$[\alpha]_{D}^{2+1}=+8.9^{\circ}$

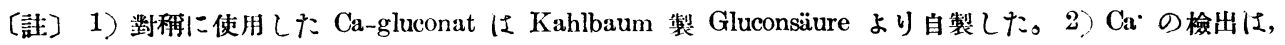
水溶液に硫酸か加へて混濁が生ずらか否かによつた。

b）水に對する溶解度の測定：

i） $24^{\circ} \mathrm{C}$ で 24 時間振擝した時の溶解度（\%)

\begin{tabular}{c|c|c|c|c|c}
\hline $\mathrm{A}$ & $\mathrm{B}$ & $\mathrm{C}$ & $\mathrm{D}$ & $\mathrm{E}$ & $\mathrm{F}$ \\
\hline 3.5 & 3.4 & 3.5 & 3.5 & 3.6 & 3.7
\end{tabular}

ii）一旦加熱して溶解せしめた後，放置して测定した時の溶解度（\%）（24-19C)

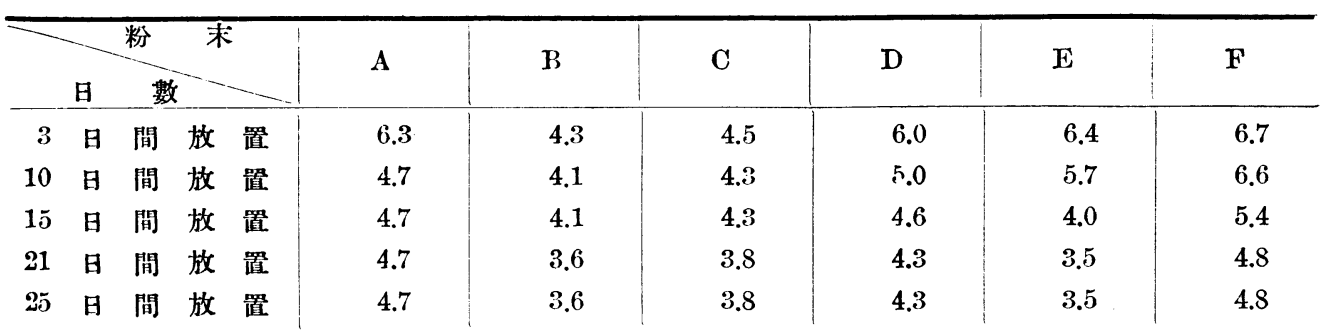

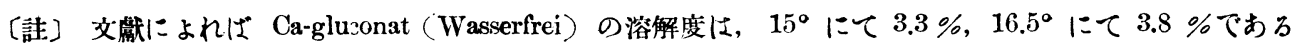
(Beilstein III. 544)。

以上に就て觀ると，Ca の量が理論值よりも幾分多く發見されたものも俆するが，市販粉末 グルコン酸石灰は, 大體に於て，各々の間に大した差は認められない.

$\mathrm{E}$ 及び $\mathrm{F}$ は， 2 分子の結晶水含有を標傍して居るが，之を直接證明するてとは出來なかつ た. 然乍ら，Ca の發見値は， 2 分子結晶水含有のものに近いと言へ妨ともない. 
又グルコン酸石灰の賞用されるのは，水溶液中でイオン化せさるにあると考へられる．との 點, 各種イオンの檢出は, 重要視さるべきであらう，乙の意味で, ハロゲンの痕跡が見出され る $\mathrm{A}$ 及び D は遺憾である.

II) 注射液に就て :

グルコン酸石灰の注射液は, 之が過飽和溶液なる點に問題が伱する（前表の如く, グルコン 酸石灰の水に對する溶解度は 3.5-4.8\% である). 即ち市販グルコン酸石灰注射液の主县の含量 を測定すると，次表の如く，甚だしく區々である．含量の测定には，蒸發殘渣の积量と更にそ れを燒き $\mathrm{CaO}$ として科量するととの方法を探用した。

次表の數字は, 躰述の如く, 月日·を異にして 2 包に瓦つて䝼入した同一種標品に就て少くと も2 包以上測定した結果の平均值であるが，测定結果は，前後の各標品に於て差異を示さなか つたので，之を以て該梅品に對する值と認めてょいであらう.

\begin{tabular}{|c|c|c|c|c|c|c|c|c|c|c|c|}
\hline \multirow{2}{*}{ 試 } & \multicolumn{3}{|c|}{$\%$ Ca-gluconat } & \multicolumn{2}{|c|}{$\% \mathrm{Ca}$} & \multirow{2}{*}{ 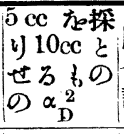 } & \multicolumn{3}{|c|}{ 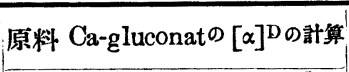 } & \multirow{2}{*}{$\left|\begin{array}{l}\text { ハロゲ } \\
\text { イォン }\end{array}\right|$} & \multirow[b]{2}{*}{$\mathrm{pH}$} \\
\hline & 記载 & \begin{tabular}{|r|} 
發 \\
蒸發殘 \\
染より
\end{tabular} & 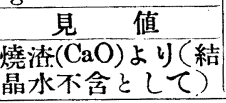 & $\begin{array}{l}\text { 發 } \\
\text { 見 }\end{array}$ & 理 & & 原料 Ca- & $\begin{array}{l}\text { gluconatり } \\
\text { 燒洫より }\end{array}$ & 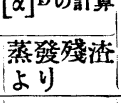 & & \\
\hline $\mathbf{A}$ & 10 & \begin{tabular}{|l|}
14.6 \\
\end{tabular} & 12.1 & 1.11 & 0.93 & $+1.32^{\circ}$ & $+26.5^{\circ}$ & $+21.9^{\circ}$ & $+18.3^{\circ}$ & +- & 5.6 \\
\hline B & 8.5 & 8.5 & 10.1 & 0.93 & 0.79 & $+0.32^{\circ}$ & $+7.5^{\circ}$ & $+6.4^{\circ}$ & $+7.5^{\circ}$. & - & "I \\
\hline C & 10 & 9.7 & 9.9 & 0.93 & 0.93 & $+0.37^{\circ}$ & $+7.4^{\circ}$ & $+7.5^{\circ}$ & $+7.6^{\circ}$ & - & " \\
\hline $\mathrm{D}$ & 8.5 & 6.7 & 7.4 & 0.69 & 0.79 & $+0.27^{\circ}$ & $+6.3^{\circ}$ & $+7.3^{\circ}$ & $+7.9^{\circ}$ & +- & "I \\
\hline E & 8.5 & 8.0 & 8.6 & 0.80 & 0.79 & $+0.32^{\circ}$ & $+7.5^{\circ}$ & $+7.4^{\circ}$ & $+7.9^{\circ}$ & - & " \\
\hline $\mathrm{F}$ & 8.5 & 8.4 & 9.3 & 0.86 & 0.79 & $+0.32^{\circ}$ & $+7.5^{\circ}$ & $+6.9^{\circ}$ & $+7.6^{\circ}$ & - & "I \\
\hline
\end{tabular}

〔註〕Ca-gluconat の〔 $\alpha]_{\mathrm{D}}$ は, $+\left(5.8 \sim 10.5^{\circ}\right.$ ) (種々の記此あり， Beilstein III. 544)

上表に見られる如く, 記載通りの含量を示したのは, 結局 $\mathrm{C}$ と $\mathrm{E} の 2$ 種に過ぎい. $\mathrm{A}$ (外 國品）は，主藥の含量が記载通りなりや否やを刵定することが出來ないがこのものの內容に關 しては後述する.

含有量の甚だしく不足なのは D である. かかる品を發賣せる會社の良心が欵はれる.

然乍ら，原料グルコン酸石灰そのものは，A 以外は，旋光度から見て先づ純粹に近いと認め てょい．佾原料の旋光度計算值表中の 3 種が一致せるものが，記截通りの含量を侍すると見ら るべきである。

份，水に對する溶解度が 3.5-4.8\% に過ぎないグルコン酸石灰を如何にして 8.5-10\% の注 射液に導くかと云へば，刎論所謂溶解補助藥が使肘される譯であるが，之に就ては立では論じ ないとととする.

双，A であるが，我くの試驗て供された品は，明かに 10\% Ca-gluconat Lösung と記載さ れて居るに拘らす，上記の如く,その蒸發殘渣が標傍量よりも，はるかに過大であり，Ca の㡎 見值も理論よりいささか多い. かかる際に，先づ考へられるのは，A が 10\%の Ca-gluconat 


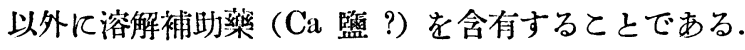

然るに最近發責のA の注射液は, $10 \% \mathrm{Ca--gluconat} \mathrm{Lösung} \mathrm{ではなく,} \mathrm{Ca-gluconat-lact-}$ obionat Lösung を標傍し. $10 \mathrm{cc}$ 中に主藥を $1.375 \mathrm{~g}$ 含有し, この $1.375 \mathrm{~g}$ は $1 \mathrm{~g}$ のa-gluconat 凡相當すると稱して居る。

そとで我ふは, 最近の A 注射液と從來の A 注射液 (即ち $10 \%$ Ca-gluconat Lösung を標 傍）との比較を試みた。

便宜上，供試品を A 及び $\mathrm{A}^{\prime}$ なる記號で示す. A は既述の $10 \%$ Ca-gluconat Lösung と 表記せるもの， $\mathrm{A}^{\prime}$ は Ca-gluconat-lactobionat entspr. 10\% Ca-gluconat を標傍せる市販品で ある.

兩者の比較は. 次表の通り。

\begin{tabular}{|c|c|c|c|c|}
\hline & 蒸發殘淕(本均) & $1 \mathrm{cc}$ の燒涼 $(\mathrm{CaO})$ (本均) & $\% \mathrm{Ca}$ & 万cc え探り $10 \mathrm{cc} と$ せるものの $\alpha_{1}^{22}$ \\
\hline $\mathbf{A}$ & $14.6 \mathrm{~g} / \mathrm{d} l$ & $15.5 \mathrm{mg}$ & 1.11 & $+1.32^{\circ}$ \\
\hline$A^{\prime}$ & $14.7 \prime \prime$ & $15.0 \mathrm{mg}$ & 1.07 & $+1.32^{\circ}$ \\
\hline
\end{tabular}

〔註〕詳細な數字は, 省くが, 蒸發殘渣の測定, $\mathrm{A}$ では 10 间の本均, $\mathrm{A}^{\prime}$ では 6 问の本均。燒渣の測定, A では 7 回, $A^{\prime}$ では 4 旬の本均。

上表により， $\mathrm{A}$ と $\mathrm{A}^{\prime}$ とが全く一致するととが登明された.

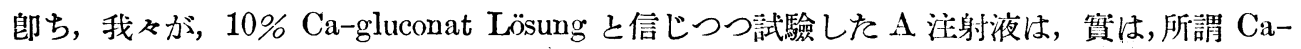
gluconat-lactobionat の溶液に他ならないととが知られた, 而して今日, 我國の枋場では, A 注射液 (郎ち 10\% Ca-gluconat Lösung 標傍) と $\mathrm{A}^{\prime}$ 注射液 (Ca-gluconat-lactobionat Lösung と表記) の 2 種が取扱はれて居るが，我ミの經驗によれば，前者の方がむしろ多い.

斯くの如く，內容が標傍とは明かに異る品を販賣しつつあるととの原因の探究は立では避け るが，少くとも良心ある製藥者の行篇とは言ひ難いであらう．而しててのととは，例へ製品が 純良で治療效果が大きくとも許さるべきではない。

以上, 市販グルコン酸石灰注射液に就ての試驗結果を綜括すると,

1）今日市販のグルコン 酸石灰注射液と稱する外國品は, グルコン酸石灰の 溶液ではなく Ca-gluconat-lactobionat なるものの溶液である.

2）國座グルコン酸石灰注射液 5 種中主藥の含量が記载通りなのは 2 種に過ぎず，極端なの は8.5\% の標傍に對し含量發見值 $6.7 \%$ に過ぎないものがある.

3）然乍ら, 國產グルコン酸石灰注射液中の原料グルコン酸石灰は, その旋光度より見て大 體純粹と認められる。

[附記]我ふは. との簡單な試驗に於て，二つの事實を發見した. 郎ち 1) 注射液中の主藥 か溧傍とは異るものの存在すること，2）注射液中の主藥の含量か記載と異るものの存在する 
こと,の二つである.

本發見が，我々に，ある種の不安感を與へたととは否定出來ない，然るに，由來，注射液に は，その內容の不明なもの，或は內容が明かでも簡單に定性或は定量出來ないものが多く，現 に我及の病院の藥品倉庫に常借せる注射液は，乙の種類 250-300 に及ぶが，乙の內容の定量可 能なものは僅かに 60 種未滿である.乙の樣な次第であるから，市販注射液の純度，含量，生

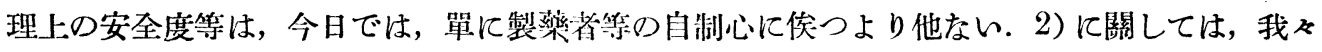
は航に「市販注射液の記載率量は信朋出來るか」なる一報告を提出したが「日本樂報第 11 年第 13 號 4 (1936)]，同報告に於て我々は，市販注射液中內容の定量可能なもの 53 種を選んで その主樂の含量を定量した處，先づ信肘して妸なるを知り，グルコン酸石灰注射液の如きは， 全く例外なるを知つたととを述へた。

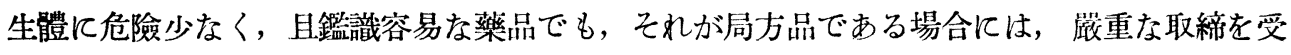

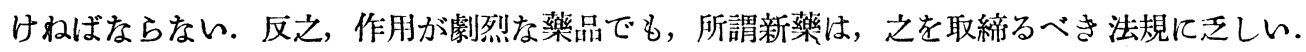
新藥には, 注射藥も多いが, 注射藥の生體に對する危險率は, 經口的藥品に比して遥かに高い. 然るに，上述の如く，之を取締るべき規格の制定には多大の困難が件ふ.

然し, 幸にも，醫療藥品に於ては，「惡貨良貨を驅逐す」の逆が恒に奥なる默に自然の法律が 存する. とは言へ, 著者等の抱いた不安感は, 直ちに, 患者及び醫師等のそれである. 我々は, 本事實の存在に對する醫藥事衞生取締當局, 製藥者乵びに藥劑師等の注意の唆起を希望するも のである.

終りに，實驗の一部を擔當された東京藥熟生徒白井亨君の勞を謝す.

\section{p-Rhodanphenylhydrazin より誘導せる Hydrazon 類に就いて（第三報）}

$\begin{array}{llll}\text { 堀 } & \text { 井善 } & \text { 一 } \\ \text { 木 } & \text { 常 }\end{array}$

(德島高等工業學校製薬化學部)

(昭和 11 年 8 月 15 日受理)

著者の一人堀井は $p$-Rhodanpheaylhydrazin を創製しその Aldehyd, Ketoa 亿對する反應を 研究中なりしが（本誌 643, $880 ； 647,53$ ) 今包 Diketon 類站に Propiophenon 類に對する 反應に關し實驗的知見を得てるを以て此處に報告せんとす. 